Corpus callosum ROls

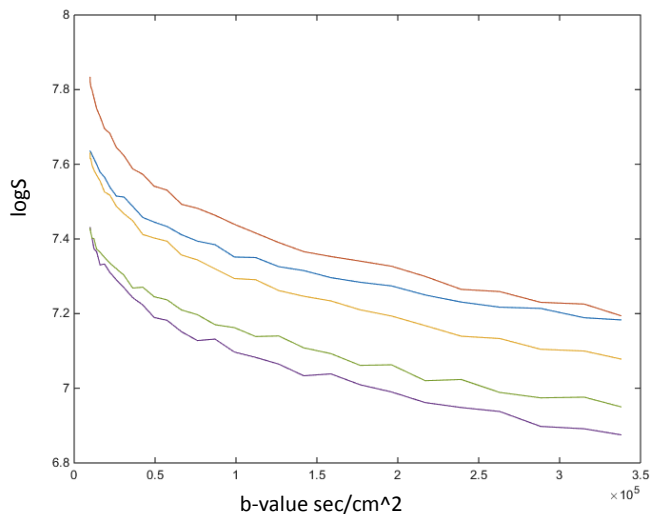

\section{Coronal ROIs}

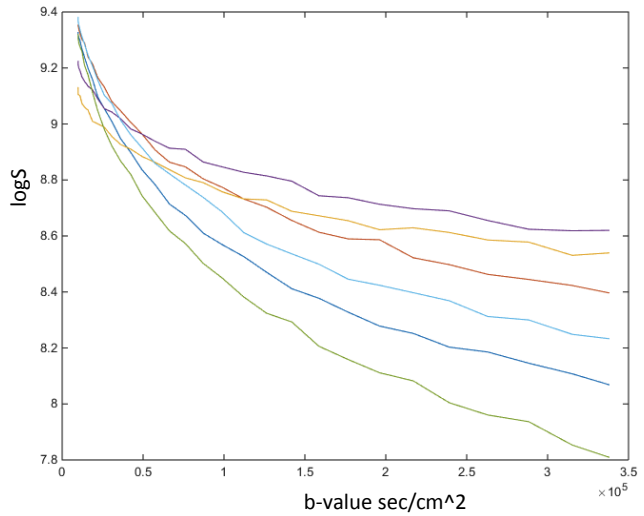

